\title{
Birds from the endangered Monte, the Steppes and Coastal biomes of the province of Río Negro, northern Patagonia, Argentina
}

\author{
Fabián A. Llanos ${ }^{1}$, Mauricio Failla ${ }^{2}$, Gustavo J. García ${ }^{1}$, Pablo M. Giovine ${ }^{3}$, Mirta Carbajal ${ }^{4}$, Patricia M. \\ González ${ }^{4}$, Daniel Paz Barreto ${ }^{5}$, Petra Quillfeldt ${ }^{6}$ and Juan F. Masello ${ }^{6 *}$
}

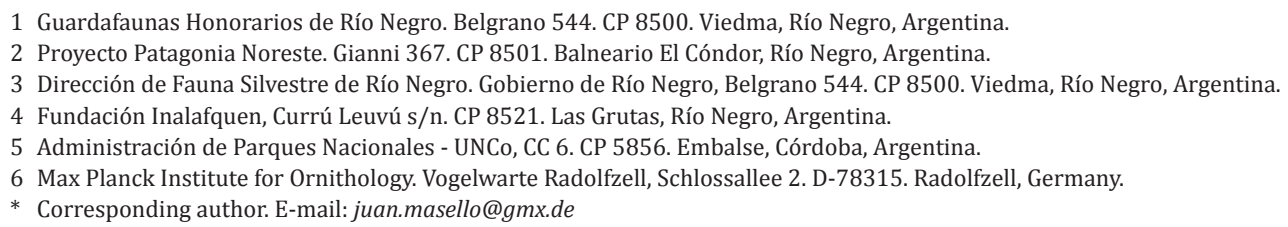

\begin{abstract}
The main ecosystem in northern Patagonia, Argentina, is the Monte, a semi-desert scrubland home to a high biodiversity. Monte is the most endangered ecosystem of southern South America, with an annual rate of clearance of the native vegetation estimated at 3.7\%. Here we report the results of bird surveys carried out in the province of Río Negro, northern Patagonia. We surveyed four localities mostly dominated by the Monte ecosystem, between 1986 and 2010 . Three localities are Important Bird Areas (IBAs): El Cóndor, San Antonio Oeste and Meseta de Somuncurá. The fourth locality is the Paso Córdoba nature reserve. We recorded a total of 263 bird species. The highest species richness was observed at San Antonio Oeste, followed by El Cóndor. Information regarding the period of occurrence and habitats are provided for all species and localities. Additionally, we indicated the cases in which breeding behavior was observed. This information is urgently needed for the evaluation of the consequences of habitat destruction and deterioration as well as for the success of intended remediation measures.
\end{abstract}

\section{INTRODUCTION}

The Monte ecosystem is a semi-desert scrubland characterized by bushy steppes and xerophytes forests, which covers approximately 46,000,000 ha and extends from Patagonia to northwestern Argentina (Cabrera 1971). Most of northern Patagonia is dominated by this ecosystem, characterized by the presence of numerous endemic species, such as insects and reptiles (RoigJuñent et al. 2001; Roig et al. 2009). Parts of this region are considered some of the last wild places on Earth (WCS and CIESIN 2005). Nevertheless, the Monte is the most endangered ecosystem in southern South America. The annual rate of clearance of native vegetation in northeastern Patagonia has been estimated at 3.7\%, a rate ten times higher than the average $0.4 \%$ rate of global tropical rainforest loss (Balmford et al. 2003; Pezzola et al. 2004). What consequences such ecosystem destruction may have for bird populations inhabiting the Monte remain unknown. It may lead to species range contractions and if the Monte disappears within the next 25 years as some predict (Pezzola et al. 2004) it will probably lead to local and/or regional population extirpations. Other habitats, with various degrees of conservation concern, are also present in northern Patagonia, including seacoast and associated cliffs and dunes, steppes, as well as large rivers with associated marshlands and ponds. An important avifauna characterizes one of these rivers, the Negro river, flowing from the Andean slopes to the Atlantic Ocean (Camperi and Darrieu 2005; Failla et al. 2007).

Northeastern Patagonia is also affected by unpredictable climatic events including the El Niño Southern Oscillation (ENSO). The region experiences dry conditions during the La Niña phase of the ENSO phenomenon, and significantly increased rainfall during El Niño years (Masello and Quillfeldt 2004a; Masello et al. 2008a). In brief, La Niña dramatically reduces food availability in the region and, as a consequence, breeding success of bird populations in the region; El Niño events trigger opposite effects. The increased ENSO frequency observed in recent years (see Masello and Quillfeldt 2004a and references therein), adds further concern regarding the viability of bird populations of the region.

Detailed observations on biodiversity are urgently needed in order to be able to study and understand the consequences of habitat destruction and deterioration, as well as the effects of climate change. Furthermore, the success of any intended conservation effort, as well as remediation actions, will also strongly depend on information from surveys. We present observational data from 25 years of surveys in northern Patagonia, Argentina, in order to update current information on the bird diversity of the region.

\section{Materials AND Methods \\ Study site}

We surveyed four localities of northern Patagonia, province of Río Negro (RN), Argentina. Three localities are Important Bird Areas (IBAs): El Cóndor (RN01: according to the Argentinean IBAs nomenclature; Di Giacomo et al. 2007), San Antonio Oeste (RN03) and Meseta de 
Somuncurá (RN06). The fourth locality is the municipal nature reserve Paso Córdoba (Figure 1).

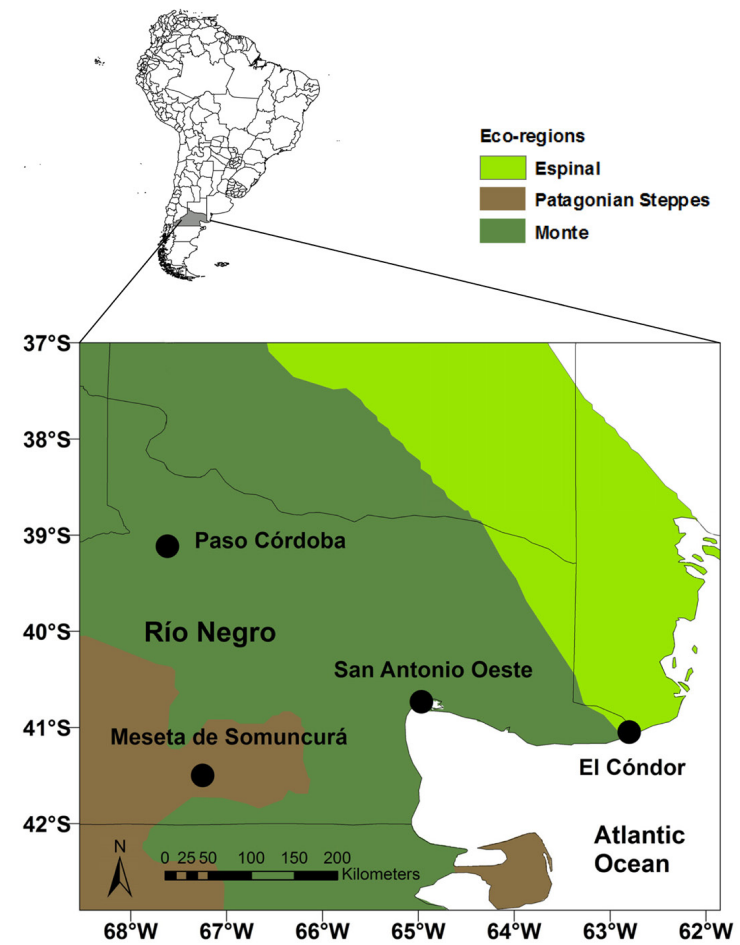

FIGURE 1. Map of northern Patagonia showing the localities surveyed in this study. The three phytogeographical provinces occurring in the region are shown in colour.

\section{El Cóndor}

The IBA El Cóndor is located in northeastern Patagonia, on the Atlantic coast (1600 ha; 41 $03^{\prime}$ S, 62 $48^{\circ}$ W; Figures 1 and 2). It is mainly characterized by remnants of Monte vegetation; however, several other habitats of importance to the local avifauna are also found: the estuary of the Negro river, its associated islands, dunes and marshlands, and sandstone cliffs (del Río et al. 2005; Lini et al. 2005; Masello and Quillfeldt 2005; Masera 2005; Olivares and Sisul 2005; Zabala and Freije 2005). Among the local vegetation, shrubs including the Chañar Geoffroea decorticans, the Piquillín Condalia microphylla, the Molle Schinus johnstonii, and the Yao-yin Lycium tenuispinosum are present (see Kröpfl et al. 2005 for further details). In El Cóndor it is also possible to find plants from the neighboring phytogeographical province of Espinal (Cabrera 1971; Masello and Quillfeldt 2005; 2007; Masello et al. 2006). The main human activities in the region are cattle ranching and local tourism in the village of El Cóndor and nearby beaches during the holiday season (Masello and Quillfeldt 2005; 2007; Torrejón and Sawicki 2005). The IBA El Cóndor lacks legal protection and consequently is highly threatened by the destruction of native Monte vegetation and resulting erosion, urban development, intensification of agricultural practices and illegal hunting of wild birds (Masello and Quillfeldt 2005; 2007).

\section{San Antonio Oeste}

The IBA San Antonio Oeste is also located in northeastern Patagonia, on the Atlantic coast (300,000 ha; 4044' S, 6458' W; Figures 1 and 3). The main habitats are: 1) the Monte vegetation in the flat and in the 'bajos' (below sea level) terrestrial areas, 2) large extensions of

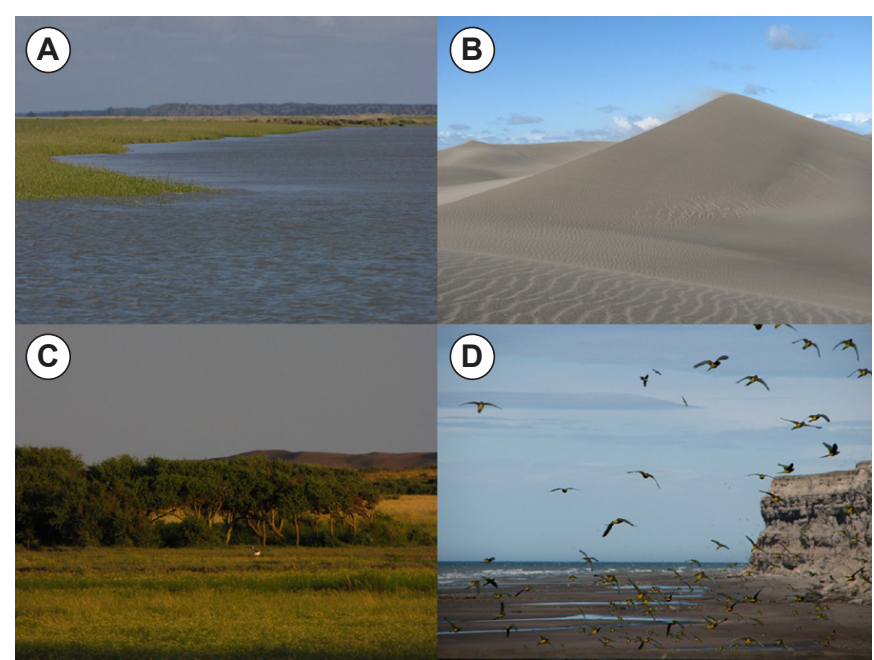

FIgurE 2. Main habitats found at the IBA El Cóndor, province of Río Negro, northern Patagonia, Argentina: A) marshlands at the estuary of the Negro river, B) dunes close to the estuary of the Negro river, C) patch of Monte vegetation close to the dunes, D) sandstone cliffs. Photos by Mauricio Failla.

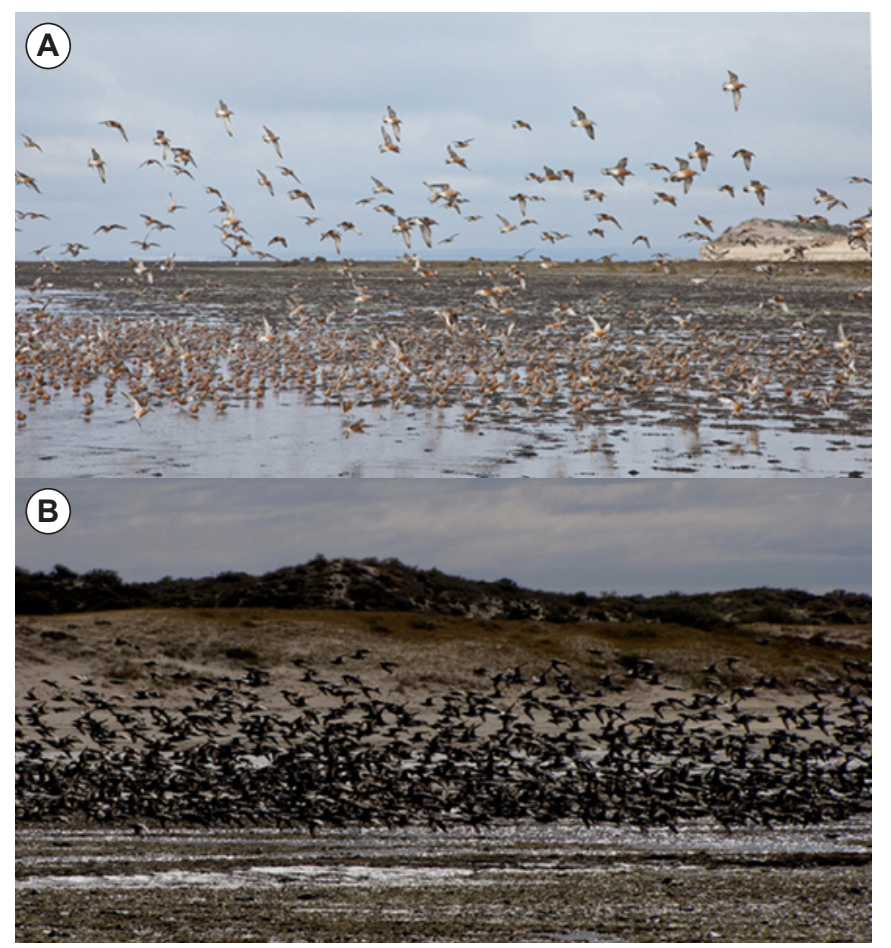

FIGURE 3. Large extensions of sandy and muddy tidal flats, with the irregular presence of shoals (A) and large dunes (B), two characteristics of the IBA San Antonio Oeste. Photos by Jan van de Kam (A) and Mauricio Failla (B).

sandy and muddy tidal flats, with the irregular presence of shoals, and large dunes, 3) sandstone cliffs (Bonuccelli 2005; González 2005; 2007; Masera 2005; Zabala and Freije 2005). The coastline is characterised by tidal amplitude of up to $9.3 \mathrm{~m}$, that can expose beaches up to $7 \mathrm{~km}$ wide during low tide (González 2005; 2007). San Antonio Oeste is renowned as a Site of International Importance by the Western Hemisphere Shorebird Reserve Network (González 2005; 2007). It is also important to note that very few freshwater sources exist in the area in the form of seasonal streams, temporary ponds and a channel that runs from the Negro river, distant some 180 km (Guarido and Mazzitelli Mastricchio 2003). Human disturbance in this IBA is related to three cities within the region, the deep-water harbor and associated fisheries 
and aquaculture, cattle ranching and tourism in the city of Las Grutas and nearby beaches during the holiday season (González 2005; 2007). Several sectors of this IBA (650 $\mathrm{km}^{2}$ ) belong to the provincial nature reserve Bahía de San Antonio (Paz Barreto 2005; González 2007). Despite this, urbanization, industrialization, the destruction of the native Monte vegetation and resulting erosion, the intensification of agricultural practices, poorly regulated fisheries and aquaculture, unregulated tourism and illegal hunting threaten the local bird community (González 2005; 2007).

\section{Meseta de Somuncurá}

The IBA Meseta de Somuncurá is located in the northern Patagonian steppes $(1,600,000$ ha in the

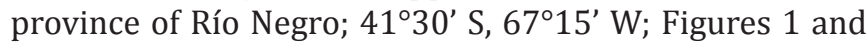
4). It is characterized by both Monte and Patagonian steppes vegetation (Cabrera 1971; Figure 1). Three main geological features characterise this IBA: a) a large plateau, with one of the few endorreic basins in South America, b) low sierras, and c) small valleys, where some streams and moorland occur (Guarido 1998; Masera 1998; Chebez 2007). This IBA is home to many endemic plants, fish, amphibians, lizards, mammals and mollusks (Paz Barreto 1998; Vinci 1998; Chebez 2007). The main human activities are associated with a small village located to the west of this IBA, cattle ranching during the summer months, and developing tourism (Cortés et al. 1998; del Valle Moldes 1998; Chebez 2007). These activities are poorly regulated and posse some degree of threat to this extremely fragile ecosystem (Chebez 2007). In addition, an increase in recreational activities in the outermost areas of the Meseta de Somuncurá has been noted close to several towns in the surrounding region (Sierra Grande, Valcheta, El Caín, Rincón Grande, in decreasing order). This is due to the use of off-road vehicles and to better road access in recent years.

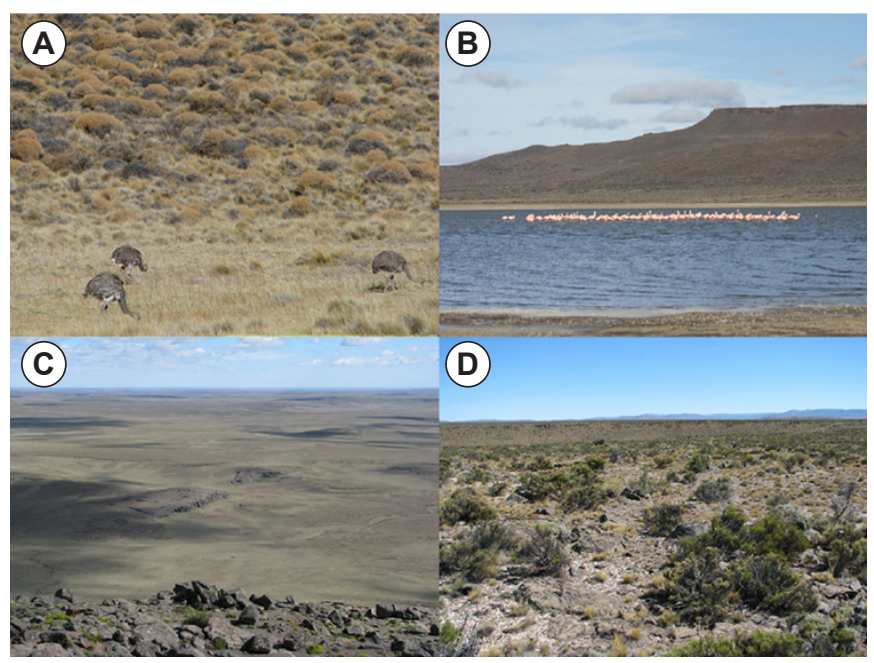

FIGURE 4. Main habitats found at the IBA Meseta de Somuncurá: A) Patagonian steppes, B) little valleys, where some freshwater is possible to be found, C) the plateu as seen from the sierras, D) the sierras as seen from the plateu (note the tipical steppe vegetation). Photos by Fabián Llanos.

\section{Paso Córdoba}

The municipal nature reserve Paso Córdoba is located in the upper valley of the Negro river, surrounded by the northern Patagonian plains $\left(17,500\right.$ ha; $39^{\circ} 07^{\prime} \mathrm{S}$, 67³7' W; Figures 1 and 5; see also Guarido 2001). This 'natural protected area', as it is oficially called in Spanish, is one of the few in Patagonia that protects a relatively large area of the phytogeographical province of Monte. As it is located $12 \mathrm{~km}$ from the city of Roca, it is close to of one of most developed urban areas of Patagonia. Additionally, the region north and east of Paso Córdoba has some of the most intense agricultural developments in Patagonia. Urbanization, industrialization, intensification of agricultural practices and associated erosion, the increased use and subsequent accumulation of pesticides for agriculture, poorly regulated local tourism and illegal hunting also threaten the bird community and ecosystem of this nature reserve (Piacentini and Paz Barreto 2001).

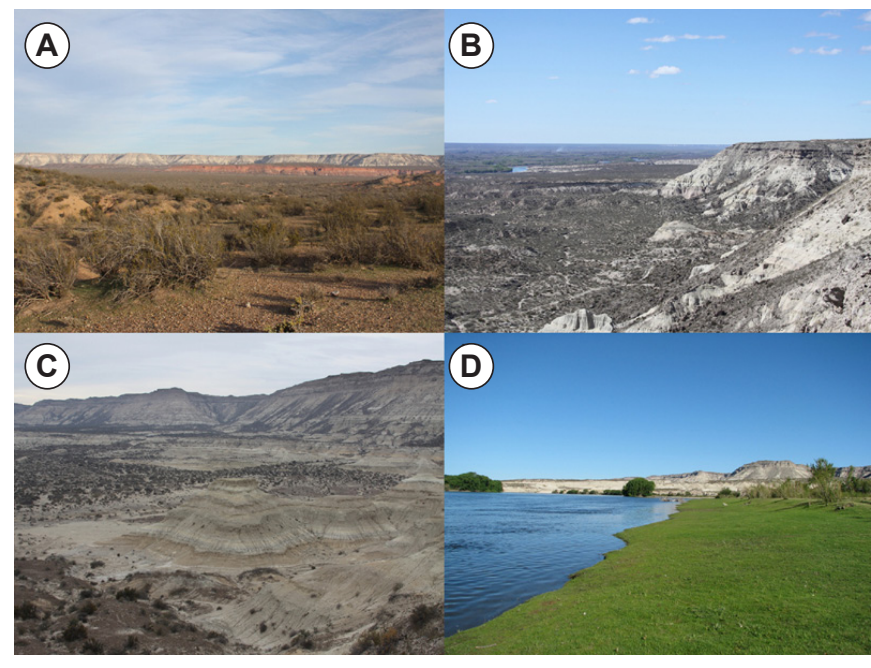

FIgURE 5. Main habitats found at the municipal nature reserve Paso Córdoba: A) and B) Monte vegetation in the valley of the Negro river, C) the 'bardas' (gorges) at the border between the valley of the Negro river and the northern Patagonian plains, D) the Negro river. Photos by Fabián Llanos.

\section{Data collection and analysis}

Although sampling effort was high during most years of the study, it differed among the studied localities. Data for El Cóndor were collected: 1) on a daily basis, all year long, between 1986 and 1989 (during some weeks of this period the frequence was reduced to once a week), 2) on a daily basis, from October to February, during the period 1998-2002; 3) two to three times per season in 2003; 4) from 2004 to 2010, during ten or more surveys in March-September (non-breeding season), and on a daily basis between October and February (breeding season). In San Antonio Oeste data were collected from: 1) one to ten surveys per moth, all-year-round, between 1989 and 1995 ; 2) one to ten surveys, in Winter, Spring and Summer, and 4 times per week in Fall, between 1995 and 1997, 3) 40 to 70 one-day surveys from February to May, and three to seven in Spring, between 1998 and 2010.

For the municipal nature reserve Paso Córdoba, data were collected: 1) during one-day surveys carried out every 15 days, all-year-round, between 2000 and 2010, 2) during additional three-days long surveys, carried out once per season, from 2000 to 2010. At the Meseta de Somuncurá the following surveys were carried out: 1) an 18 days survey in November and December 1993, 2) a four days survey in August 2006, 3) a five days survey in September 2007,4) a four days survey in August 2008, and 
5) two to three several-days surveys per season between 2004 and 2009.

For all birds observed, we recorded species identity, habitat, and period of occurrence (season). Observations were carried out along regularly surveyed pathways by at least two of us. We also recorded whether the bird was breeding in the area or not. A bird was considered breeding in a given locality if any of the following criteria were fulfilled: 1) presence of a colony, 2) presence of a nest, or 3) observation of juvenile birds during the known breeding season. Birds were observed and identified with the assistance of binoculars and telescopes. Species identification was carried out using all the field guides available (Olrog 1959; de la Peña 1988; 1989; 1992a,b,c, de la Peña and Rumboll 1998; Narosky and Yzurieta 1989; 2003; 2010). Taxonomic position and scientific names followed Mazar Barnett and Pearman (2001), except in a few cases indicated (Table 1).

In order to compare the similarity of species composition, we calculated the Jaccard coefficient (also known as Jaccard index, or Jaccard similarity coefficient) among all pairs of localities. The Jaccard coefficient measures similarity between sample sets, and is defined as the size of the intersection divided by the size of the union of the sample sets (Real and Vargas 1996).

\section{RESULTS AND DISCUSSION \\ Overall}

We recorded 263 bird species (161 non Passeriformes and 102 Passeriformes) belonging to 55 families (Table 1). Most species belonged to the Monte, Espinal and coastal bird communities as defined by Narosky and Yzurieta (2003). The highest species richness was recorded at the IBA San Antonio Oeste (205 species), followed by the IBA El Cóndor (185), the nature reserve Paso Córdoba (157), and the IBA Meseta de Somuncurá (109). The Jaccard coefficient among all pairs of localities showed a clear differentiation of the IBA Meseta de Somuncurá with respect to coastal localities (El Cóndor and San Antonio Oeste), and a higher degree of similarity between the IBAs San Antonio Oeste and El Cóndor (Table 2).

\section{San Antonio Oeste}

We recorded 14 threatened bird species in the IBA San Antonio Oeste (Table 1): the Darwin's Rhea Rhea [Pterocnemia] pennata (d'Orbigny, 1834), the Rockhopper Penguin Eudyptes chrysocome (Forster, 1781), the Macaroni Penguin E. chrysolophus (Brandt, 1837), the Magellanic Penguin Spheniscus magellanicus (Forster, 1781), the Black-browed Albatross Thalassarche melanophris (Temminck, 1828), the Wandering Albatross Diomedea exulans (Linnaeus, 1758), the Royal Albatross D. epomophora (Lesson, 1825), the Common GiantPetrel Macronectes giganteus (Gmelin, 1789), the Whitechinned Petrel Procellaria aequinoctialis (Linnaeus, 1758), the Sooty Shearwater Puffinus griseus (Gmelin, 1789), the Chilean Flamingo Phoenicopterus chilensis (Molina, 1782), the Two-banded Plover Charadrius falklandicus (Latham, 1790), the Hudsonian Godwit Limosa haemastica (Linnaeus, 1758), the Red Knot Calidris canutus (Linnaeus, 1758), the Sanderling C. alba (Pallas, 1764), the Whiterumped Sandpiper C. fuscicollis (Vieillot, 1819), the
Magellanic Plover Pluvianellus socialis (Gray, 1846), the Olrog's Gull Larus atlanticus (Olrog, 1958), the Chocolatevented Tyrant Neoxolmis rufiventris (Vieillot, 1823), and the Yellow Cardinal Gubernatrix cristata (Vieillot, 1817).

Previous studies also reported all of these species for the IBA San Antonio Oeste suggesting that this IBA might be important for them (González 2005; 2007; Piacentini and Dallorso 2005). Nevertheless, we found that eight of these threatened species were occasional visitors to the region (Table 1). Moreover, we could only confirm $R$. pennata, $C$. falklandicus, and G. cristata as breeding birds in the area (Table 1). Yet this finding is of remarkable importance, particularly for the latter species, which is currently highly threatened by habitat lost and trapping for the pet trade (Failla et al. 2007). As P. chilensis and N. rufiventris were present all year round (Table 1; see also González 2007) it is possible that these species actually breeds in the region, but we were not able to detect breeding behavior, colonies, or nests. Other species like $S$. magellanicus, M. giganteus, $P$. socialis and $L$. atlanticus were regular visitors during the non-breeding season (Table 1) but always in low numbers.

San Antonio Oeste is an important place for waders (González 2005 and references therein). We recorded 15 Nearctic shorebirds using San Antonio Oeste as migration stop-over (Table 1), of which C. canutus, C. alba, C. fuscicollis, L. haemastica, and the Grey Plover Pluvialis squatarola (Linnaeus, 1758) were observed in large numbers, particularly during the Austral Fall (Table 1). Between February and April, varying among years, 25 to $50 \%$ of the total population of C. c. rufa makes stopover in San Antonio Oeste on their way back to the Northern Hemisphere (González et al. 2004; 2006; González 2007).

\section{El Cóndor}

We also observed nine threatened species at El Cóndor: the Greater Rhea Rhea americana (Linnaeus, 1758), S. magellanicus, T. melanophris, M. giganteus, $P$. chilensis, the Ruddy-headed Goose Chloephaga rubidiceps (Sclater, 1861), L. atlanticus, G. cristata, and the Pampas Meadowlarck Sturnella defilippii (Bonaparte, 1850) (Table 1). We found that three of these species breed at el Cóndor (Table 1). Individuals of $R$. americana were observed breeding in farmland with extensive cattle ranching and in Monte patches, while the G. cristata were nesting in remnant patches of undisturbed Monte vegetation (Table 1). Adults of $S$. defilippii were found breeding at the marshlands on the western side of the estuary of the Negro river during spring 2006. This breeding place was located some $200 \mathrm{~km}$ south of the previously known breeding areas (Fernández et al. 2003; Cozzani et al. 2004; Gabelli et al. 2004). This finding is of paramount importance for bird conservation as $S$. defilippii is an endemic, vulnerable species from Argentina (Tubaro and Gabelli 1999).

Another species found in El Cóndor, some $200 \mathrm{~km}$ out of its normal range (see Mazar Barnett and Pearman 2001; Narosky and Yzurieta 2003), was the Limpkin Aramus guarauna (Linnaeus, 1766) (Table 1). Although several individuals were observed in the marshlands on the western side of the estuary of the Negro river in all seasons during the last two years, breeding could not be confirmed (Table 1). Groups of up to 20 L. atlanticus regularly used the islands, sand banks and marshlands on 
the western side of the estuary of the Negro river. These are probably individuals from several colonies of this species located at the IBA San Blas (BA16), about $100 \mathrm{~km}$ to the north of the estuary of the Negro river, which would represent $38 \%$ of the breeding population of the species (Rabuffetti 2007). The marshlands at the estuary of the Negro river also attracted several species of waders: we recorded eight Neartic migrants, three resident species, and two Neotropical migrants (Table 1).

The most striking ornithological feature of El Cóndor is the colony of the Burrowing Parrot Cyanoliseus patagonus (Vieillot, 1818) (Masello and Quillfeldt 2005; 2007; Masello et al. 2006). The C. patagonus colony extends along $12.5 \mathrm{~km}$ of sandstone cliffs facing the Atlantic Ocean in the westernmost part of this IBA (Masello et al. 2006; Failla et al. 2007). A detailed study showed that the colony contained $>50,000$ burrows, an estimated $>37,000$ of which were active (Masello et al. 2006). To our knowledge, this is the largest known colony of Psittaciformes of the world. Note that Masello et al. (2006) mentioned an extension of the colony of only $9 \mathrm{~km}$. In the years after that study, the colony expanded further westwards reaching its present extension (12.5 km). Additionally, 6500 C. patagonus not attending nestlings were found to be associated with the colony during counts carried out in the 2003-2004 breeding season (Masello et al. 2006). Several other bird species use collapsed $C$. patagonus nests for their own breeding, including high numbers of the Southern Martin Progne modesta (Gould, 1838) (see Masello and Quillfeldt 2005), the Chimango Caracara Milvago chimango (Vieillot, 1816), the American Kestrel Falco sparverius (Linnaeus, 1758), the Peregrine Falcon Falco peregrinus (Tunstall, 1771), the Common Barn Owl Tyto alba (Scopoli, 1769), and the Field Flicker Colaptes campestris (Vieillot, 1818) (Masello et al. 2008b). These findings support El Cóndor as a region of critical importance for the avifauna of NE Patagonia. Paradoxically, the IBA El Cóndor lacks legal protection, which is urgently needed in order to protect its bird community (Masello and Quillfeldt 2003, 2004b, 2005, 2007; Masello et al. 2007; Masello 2009).

\section{Paso Córdoba}

At the municipal nature reserve Paso Córdoba we detected birds species mainly associated with the Monte ecosystem or to the Negro River (Table 1). Among the Monte species, we found two partial austral migrants: the Rusty-backed Monjita Neoxolmis rubetra (Burmeister, 1860) and the Austral Negrito Lessonia rufa (Gmelin, 1789) (Table 1). We also detected two threatened species, the $R$. [Pterocnemia] pennata and P. chilensis (Table 1). In addition, we detected $A$. guarauna at Paso Córdoba, suggesting a recent expansion of this species into northern Patagonia (see above, El Cóndor). It is also important to note that we observed large flocks of the Andean Swift Aeronautes andecolus (d'Orbigny and Lafresnaye, 1837) at Paso Córdoba all-year-round (Table 1). It is regularly seen in other parts of the Monte ecosystem, but these swifts are usually found much further north. To our knowledge, this is the first observation of the species in northern Patagonia (Paz Barreto 1997a,b; Piacentini and Paz Barreto 2001). The species richness at Paso Córdoba was lower than in the coastal localities investigated (see also Piacentini and
Paz Barreto 2001; Tables 1 and 2). This was due to the absence of seabirds and the low number of wader species recorded, as Paso Córdoba is far from the sea.

The southern limit of the distribution of the Rufous Hornero Furnarius rufus (Gmelin, 1788) was considered to be the Colorado River, northern limit of Patagonia, until the 1960s (Gazari 1967). Our observation of F. rufus breeding in all four surveyed localities provide further support for the range expansion of this species towards the south. This expansion was first mentioned by Gazari (1967) and confirmed by other studies (Navas 1970; Bettinelli and Chebez 1986; Canevari et al. 1992; Paz Barreto 1997a,b).

\section{Meseta de Somuncurá}

We confirmed the presence of all species first observed in the Meseta de Somuncurá by Bettinelli and Chabez (1986): the Southern Lapwing Vanellus chilensis (Molina, 1782), C. campestris, the Black-billed Shrike-Tyrant Agriornis montana (d'Orbigny and Lafresnaye, 1837), the White-browed Ground-Tyrant Muscisaxicola albilora (Lafresnaye, 1855), the Ochre-naped Ground-Tyrant $M$. flavinucha (Lafresnaye, 1855), the Cinnamon-bellied Ground-Tyrant M. capistrata (Burmeister, 1860), the Blackfronted Ground-Tyrant M. frontalis (Burmeister, 1860), the Spot-billed Ground-Tyrant M. maculirostris (d'Orbigny and Lafresnaye, 1837), and the Grey-hooded Sierra-Finch Phrygilus gayi (Gervais, 1834) (Table 1). The breeding of $M$. capistrata in the Meseta de Somuncurá, as suggested by Chebez (2007), was not confirmed. Among threatened species, we observed the presence of $R$. pennata, the Andean Condor Vultur gryphus (Linnaeus, 1758) (recently reintroduced to Northeastern Patagonia; see Jácome et al. 2005), P. chilensis, C. rubidiceps, and N. rufiventris (Table 1). As in previous studies, our data correspond to observations carried out mainly in the Spring and Summer. Thus, data from Winter months are still needed, as pointed out by Chebez (2007). Altogether, we found a significantly larger number of species than any previous studies in the Meseta de Somuncurá and the surrounding region (Daciuk 1979; Bettinelli and Chebez 1986; Navas and Bó 1990; Canevari et al. 1992; Vuilleumier 1994; Lambertucci et al. 2009). However, as Chebez (2007) suggested, taking into account the isolation of most of this study site, and the high number of endemic species in other taxa, studies that are more detailed would be desirable in order to investigate potential population differentiation and speciation.

\section{Further remarks}

The current list of long-term bird observations in four localities of northern Patagonia, together with information on habitat use and breeding, substantially improves the knowledge of the regional avifauna. Moreover, the rate of Monte clearance in northern Patagonia (see Pezzola et al. 2004) makes this kind of studies urgent, as they will allow us to take the necessary conservation and remediation actions, based on current field data. As Paz Barreto (1997c) found in his analysis, the Monte and Espinal are indeed the two ecosystems in major need of conservation and remediation actions in the province of Río Negro, Patagonia. We expect that our study trigger more intense and detailed ornithological research in the region. 


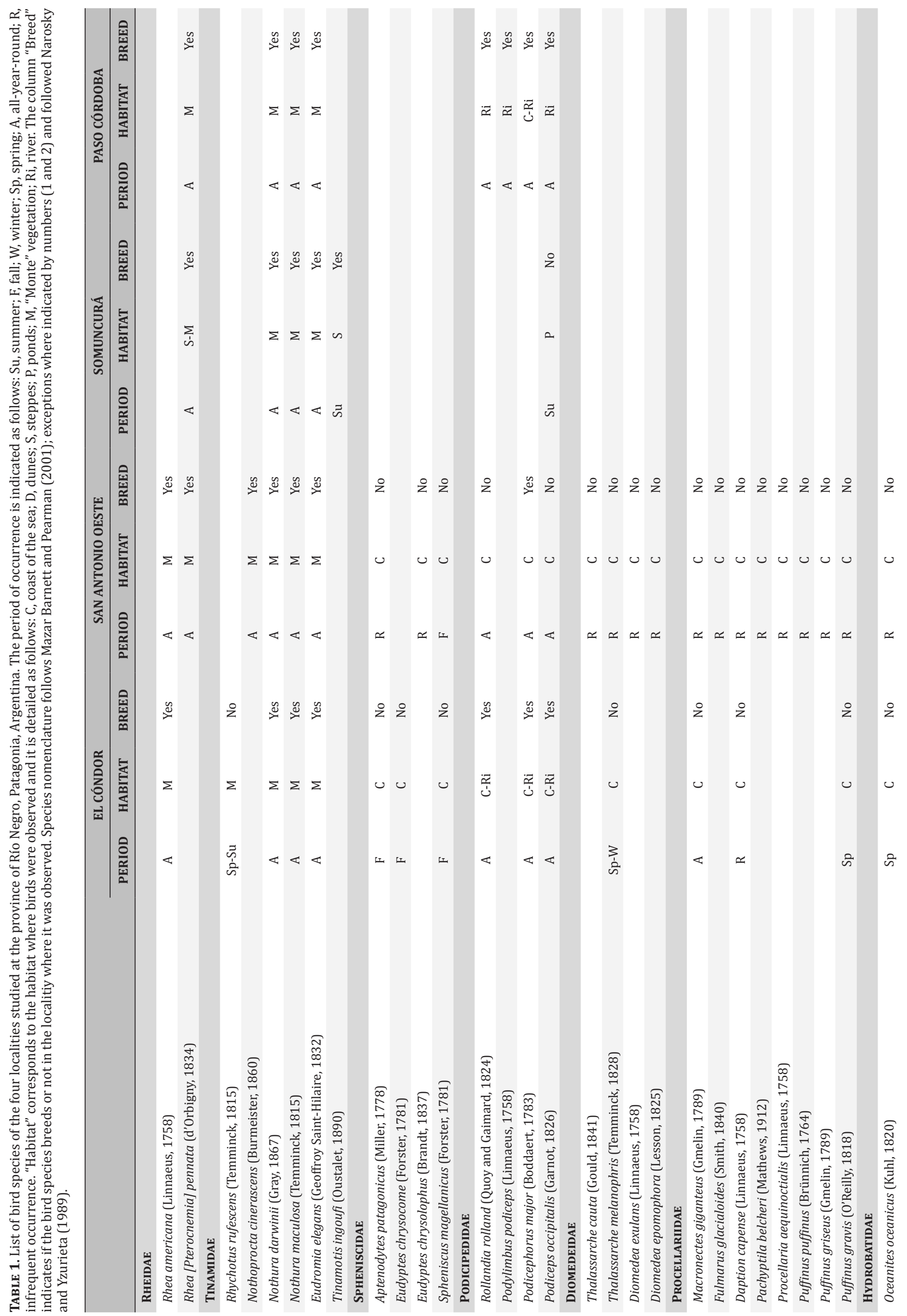




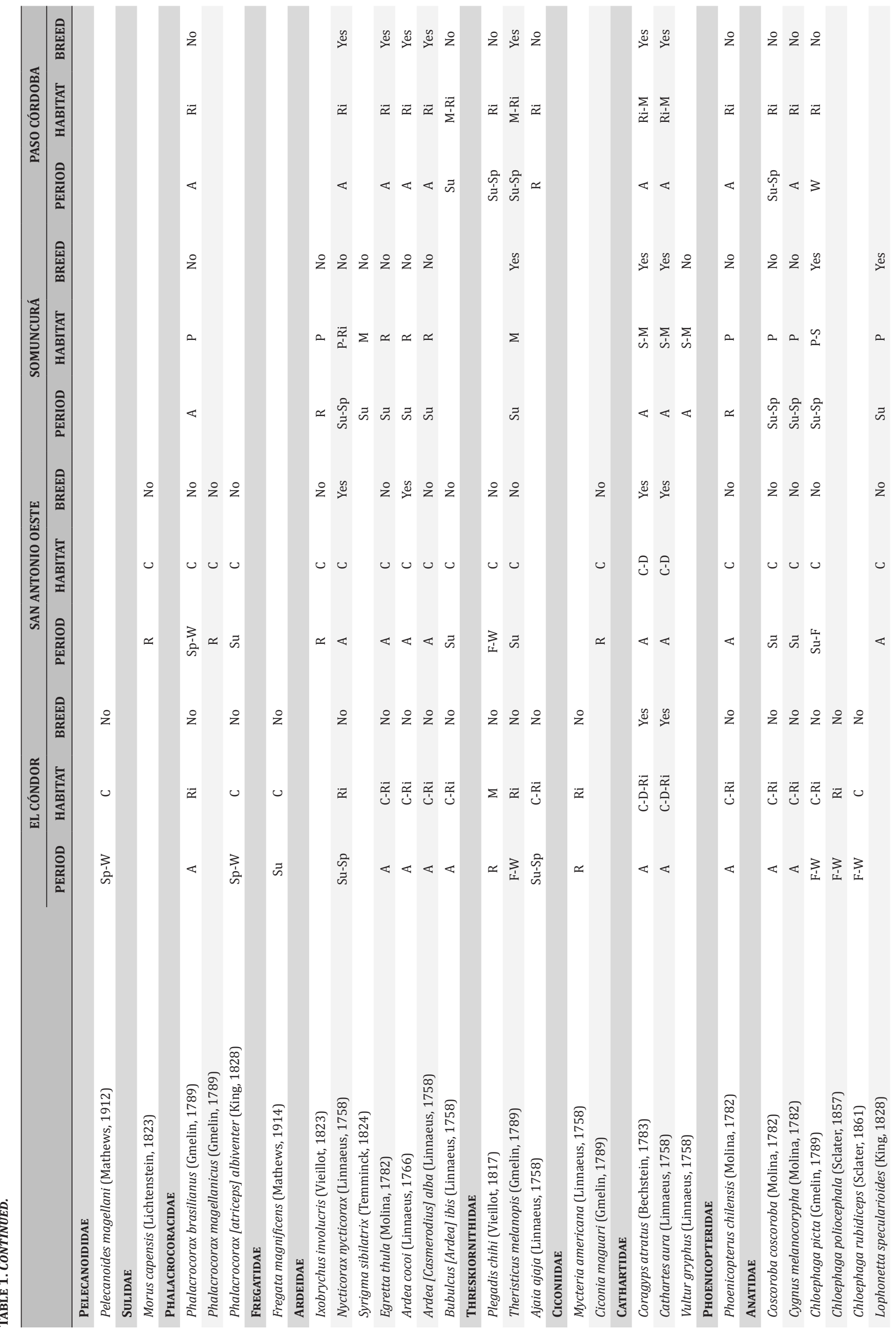




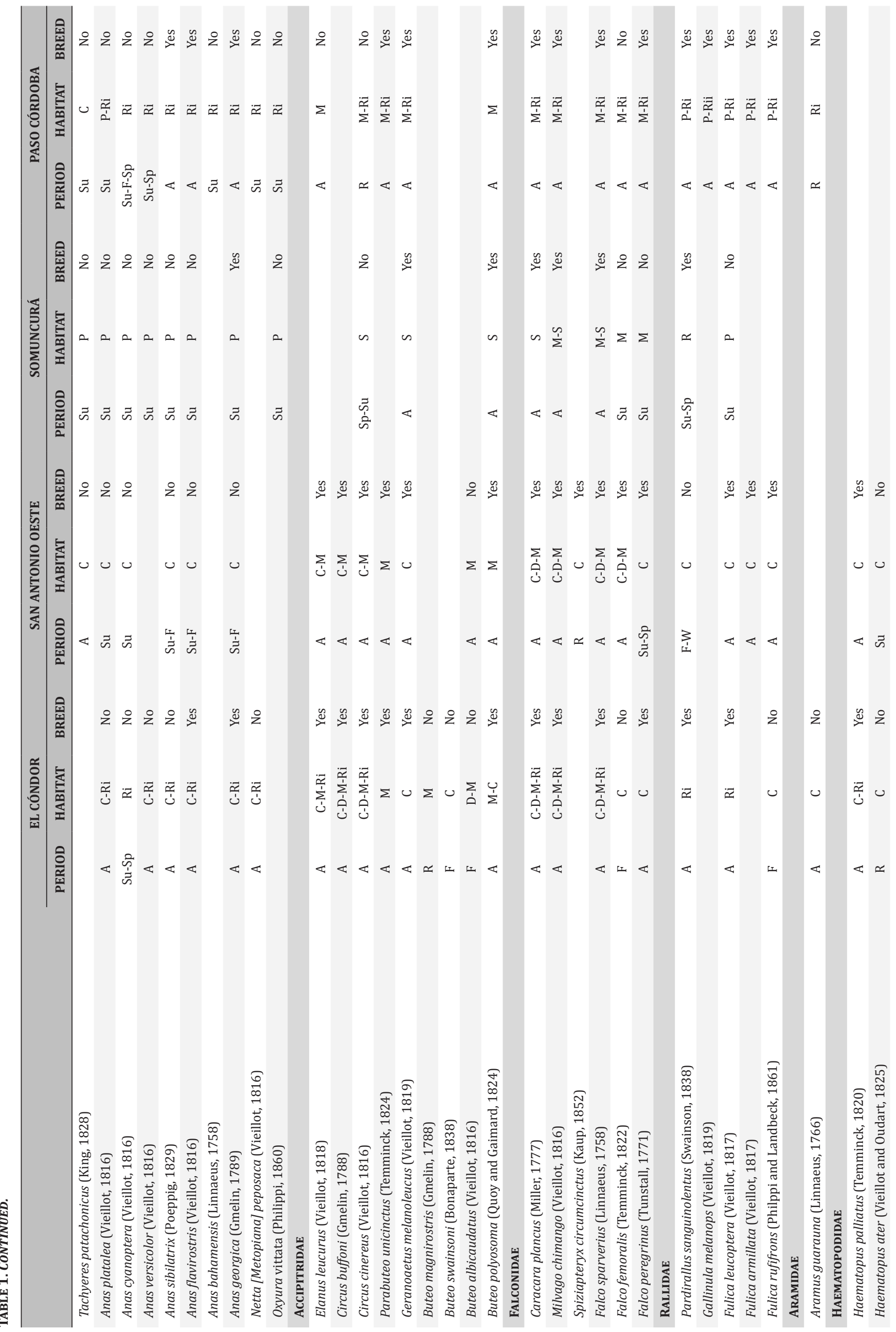




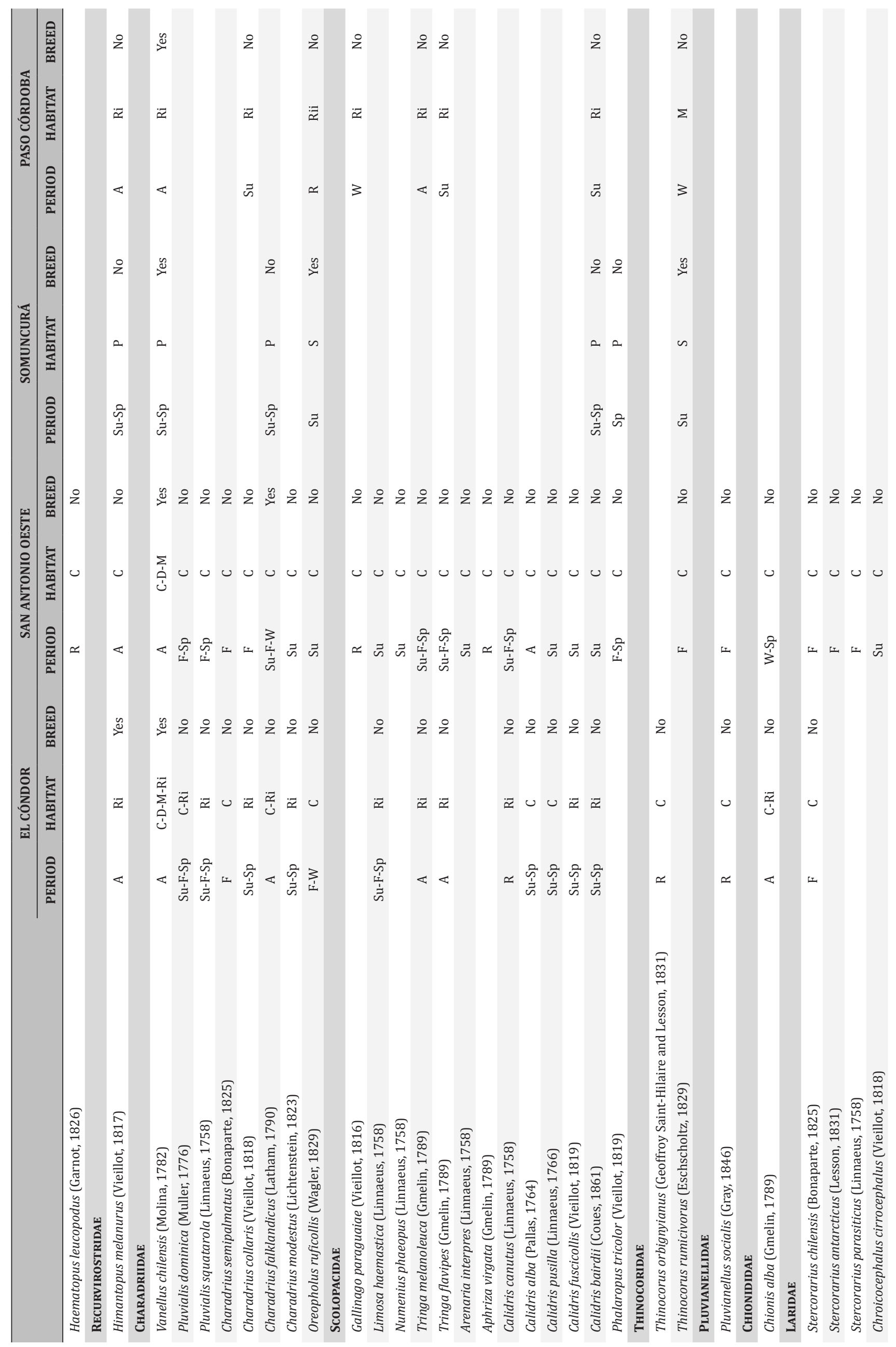




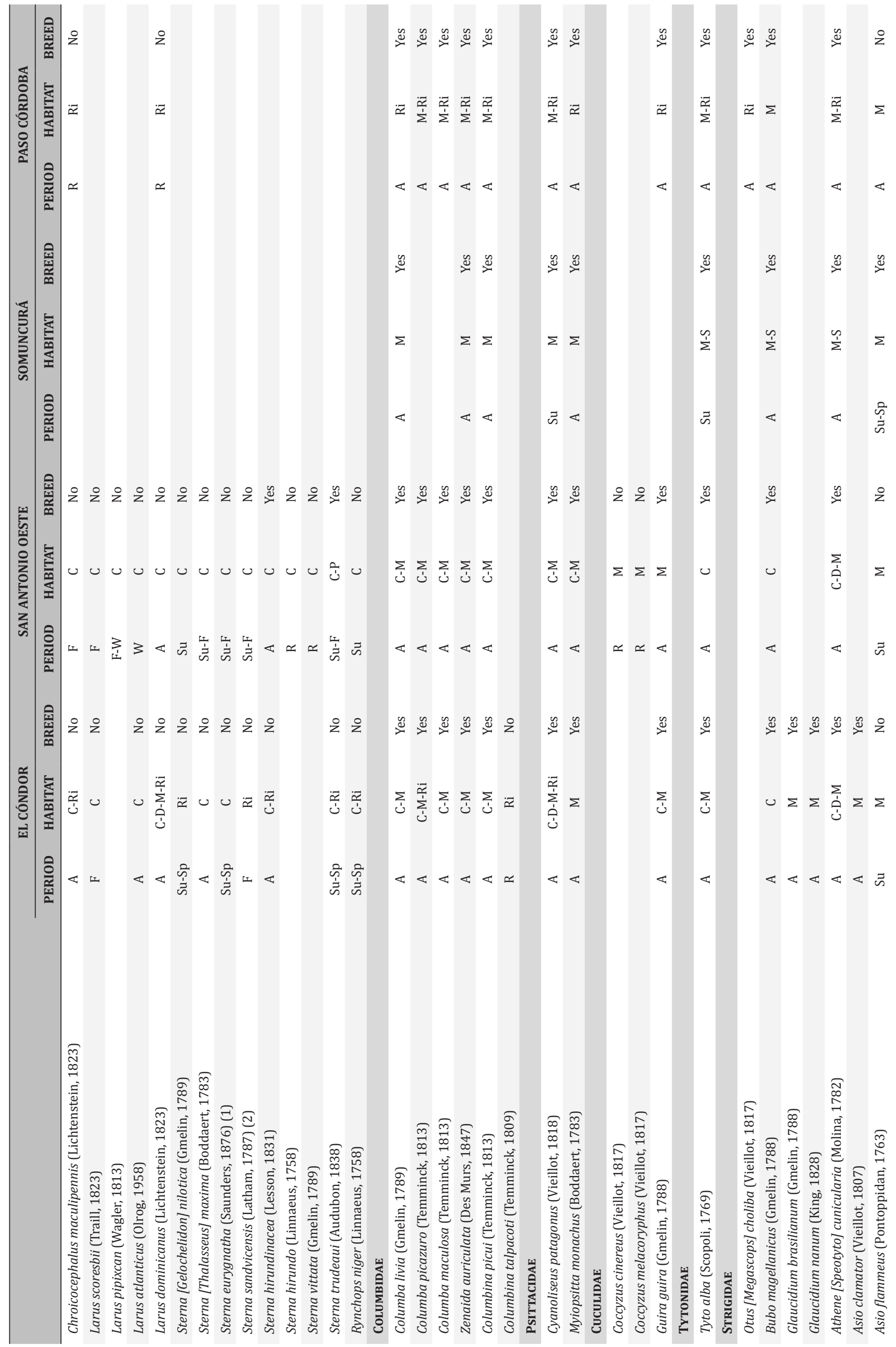




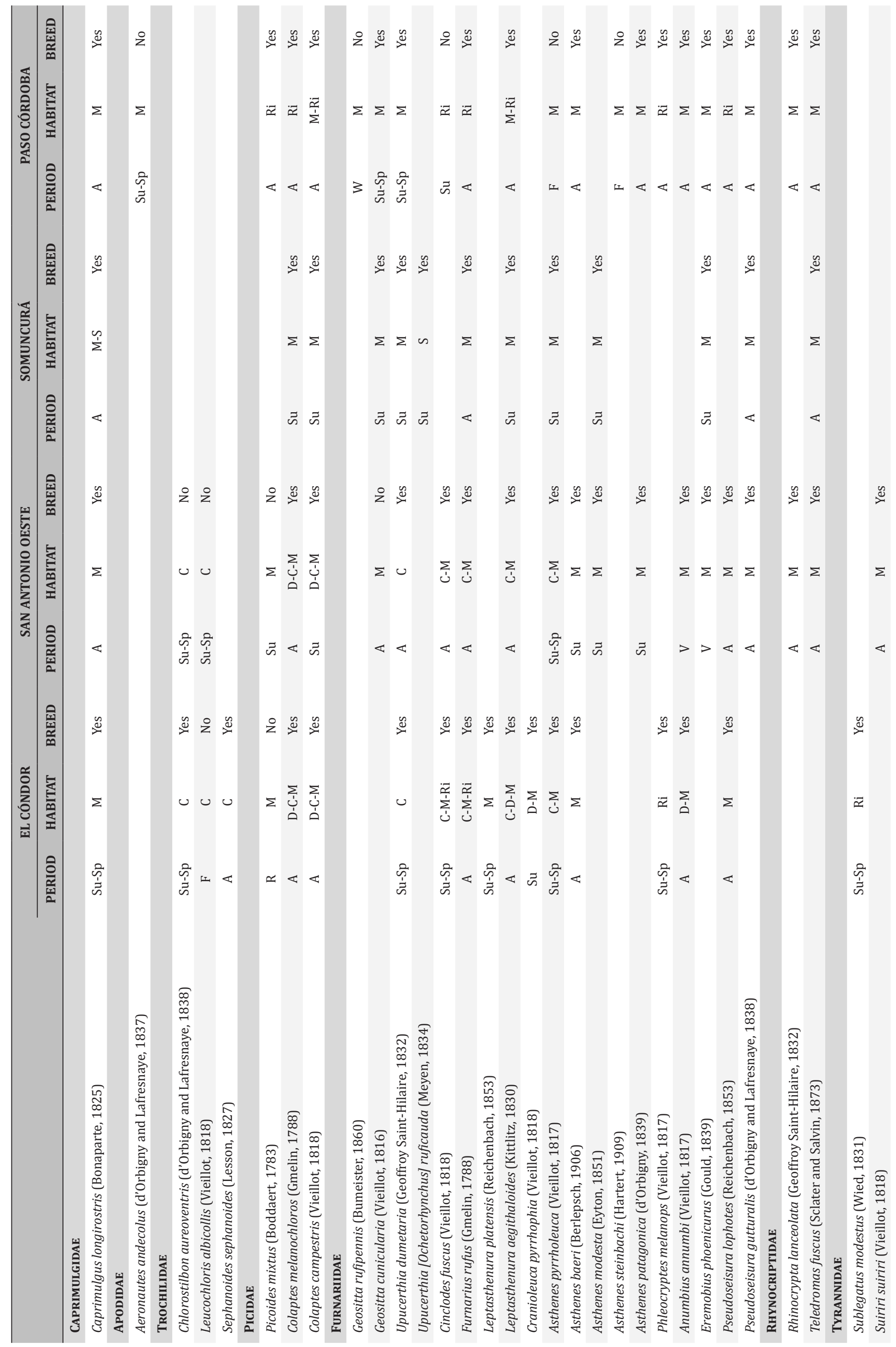




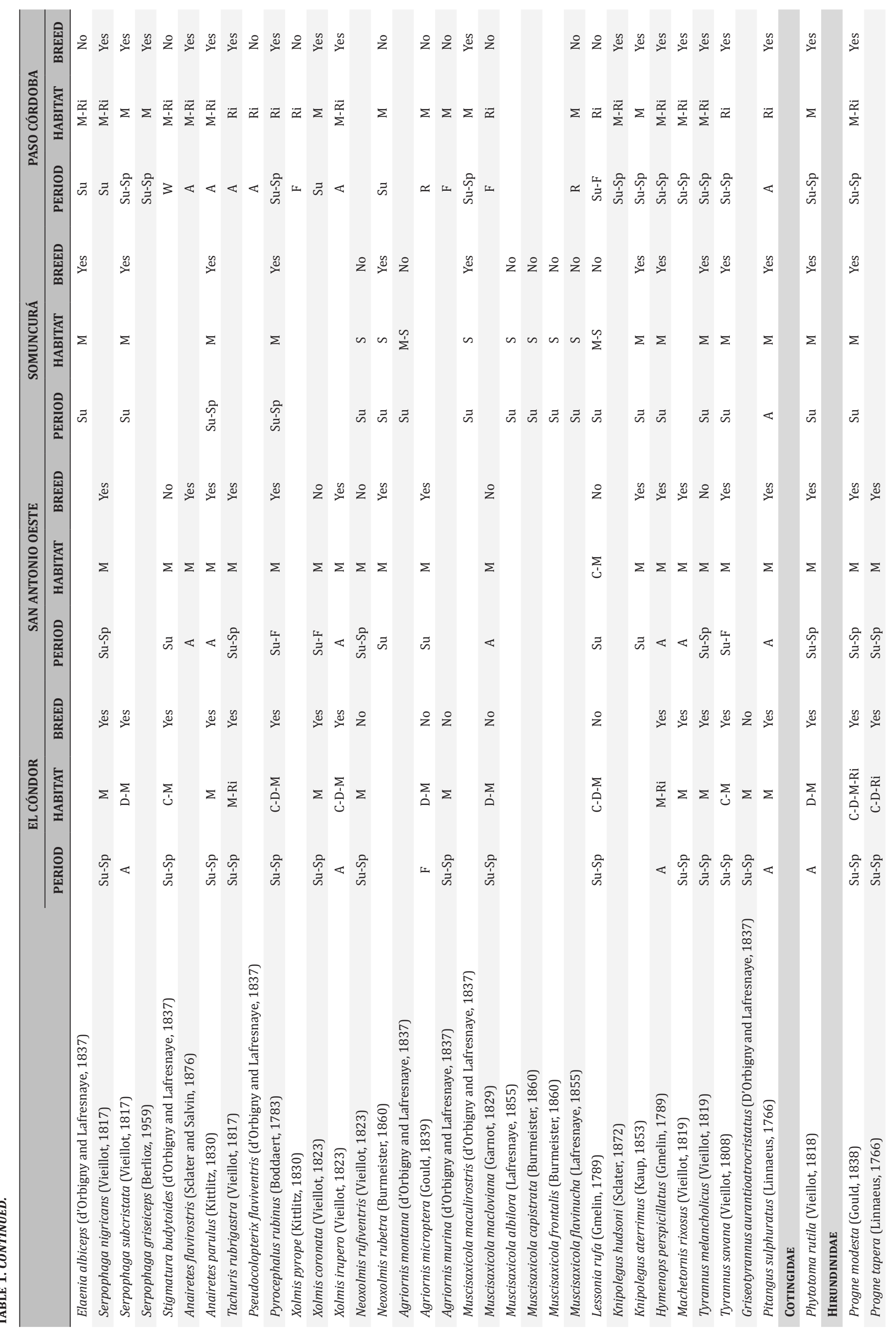




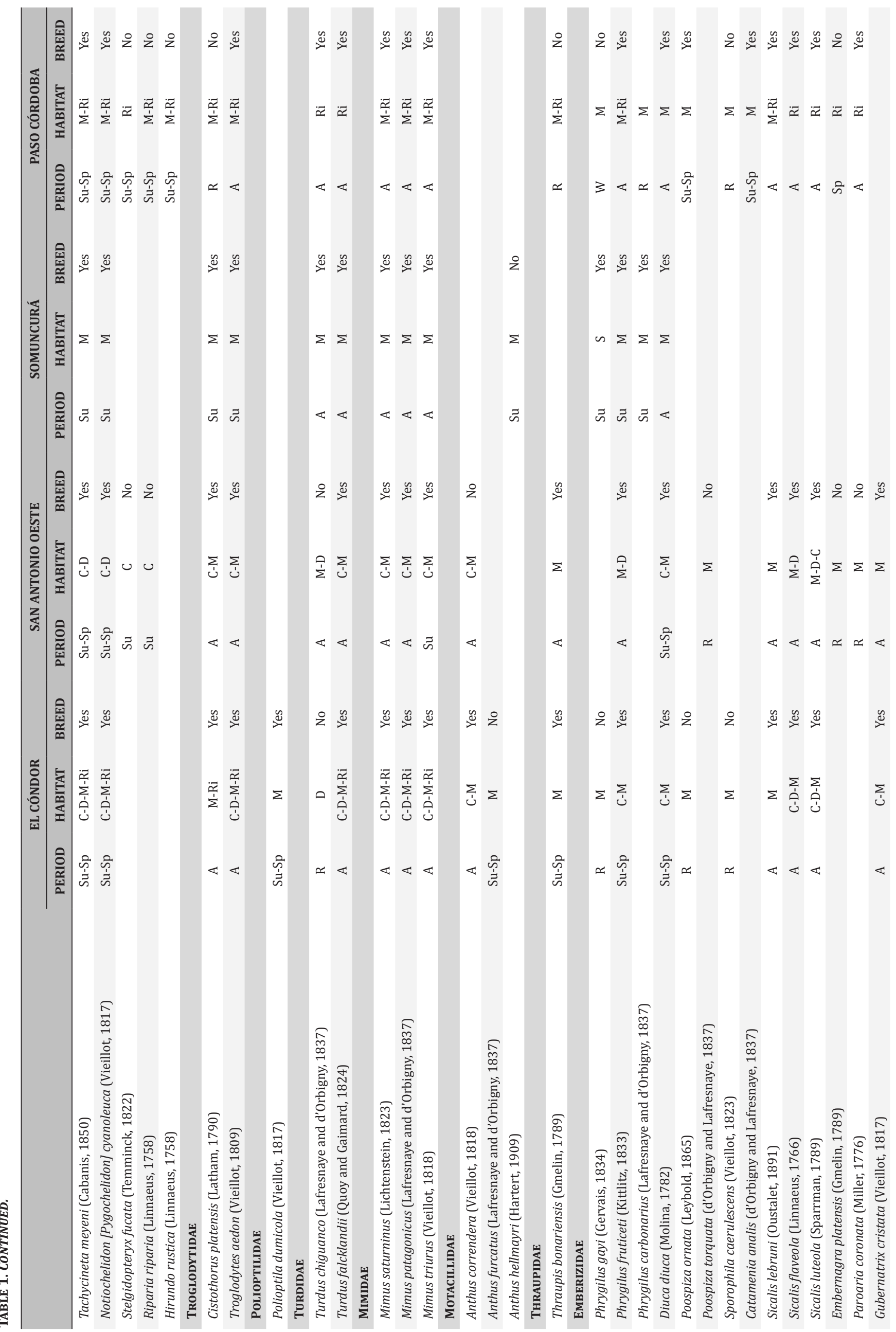




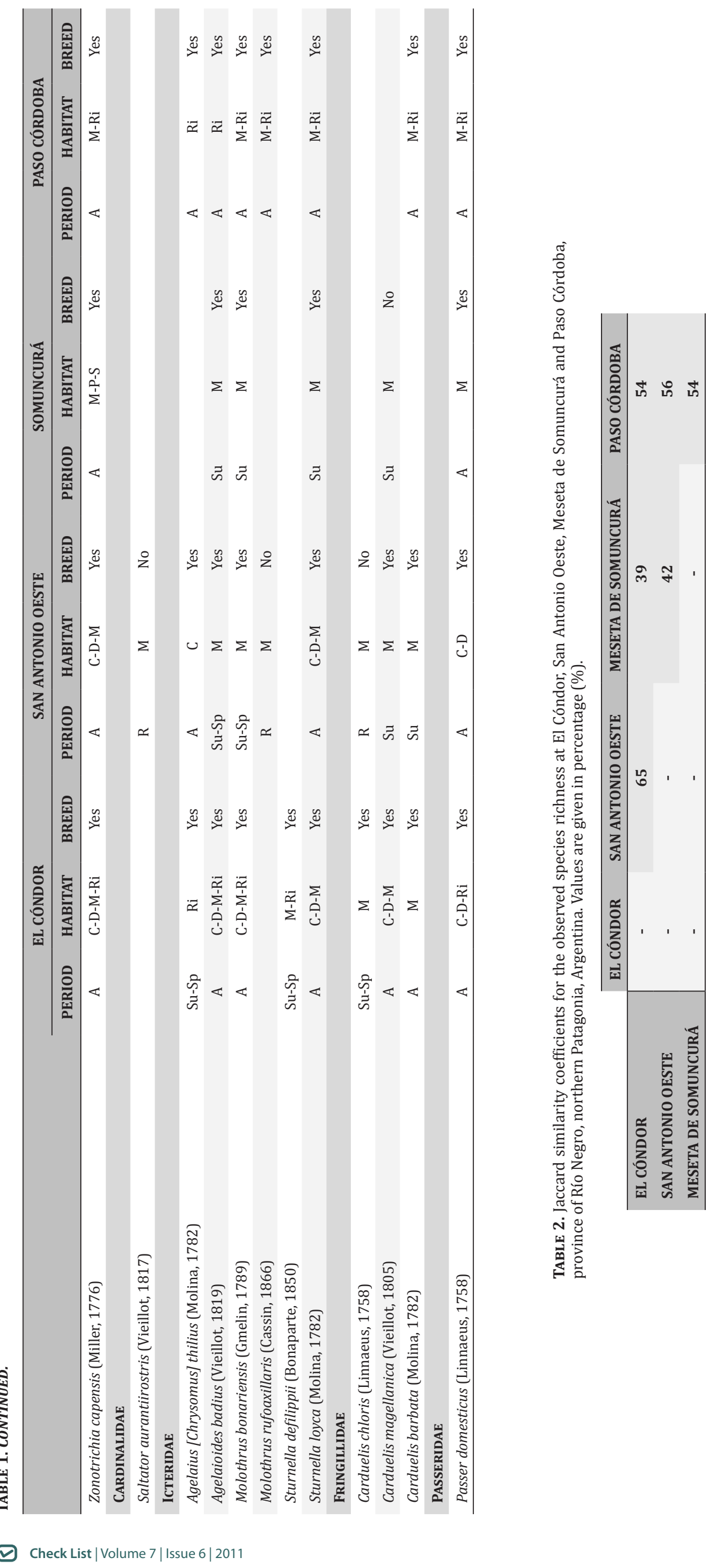


ACKNOWLEDGMENTS: We would like to thank Ignacio Areta, Maximiliano Bertini, Ramón Conde, Javier Correa, Gert Dahms, Martín Fernández, Ignacio Hernández, Oscar Lema, Mara Marchesan, Adrián Pagnossin, María L. Pagnossin, Jaime Prieto, Verónica Seijas, Tina Sommer and Roberto Ure for their help with the surveys or for providing assistance with species identification. We also would like to thank Sergio Lambertucci and two other anonymous reviewers for constructive suggestions. This project was partially supported by several grants to JFM: the City Council of Viedma (Argentina), a grant of the state of Thuringia (Germany), a co-operation grant between the International Bureau of the BMBF of Germany (ARG 99/020) and the Argentinean SECyT (AL/A99-EXIII/003), several grants from the World Parrot Trust, several grants from the Liz Claiborne Art Ortenberg Foundation and the Wildlife Conservation Society. The present study was carried out with permission of the Dirección de Fauna Silvestre de la Provincia de Río Negro, Argentina (Exp. no. 143089-DF-98).

\section{Literature Cited}

Balmford, A., R.E. Green and M. Jenkins. 2003. Measuring the changing state of nature. Trends in Ecology and Evolution 18(2): 326-330.

Bettinelli, M.D. and J.C. Chebez. 1986. Notas sobre aves de la meseta de Somuncurá. Hornero 12(2): 230-234.

Bonuccelli, R. 2005. Los acantilados del Balneario Las Grutas. Procesos que intervienen sobre el litoral. Destrucción de los acantilados. Medidas preventivas para que se transformen en estructuras estables; p. 221-234 In R.F. Masera, J. Lew and G. Serra Peirano (ed.). Las mesetas patagónicas que caen al mar: la costa rionegrina. Viedma: Ministerio de Familia, Gobierno de Río Negro.

Cabrera, A.L. 1971. Fitogeografía de la República Argentina. Boletín de la Sociedad Argentina de Botánica 14(1): 1-42.

Camperi, A.R. and C.A. Darrieu. 2005. Aves del alto valle del Río Negro, Argentina. Revista del Museo Argentino de Ciencias Naturales, Nueva Serie 7(1): 51-56.

Canevari, M., R. Chiesa and G. Lingua. 1992. Relevamiento de la meseta de Somuncurá. Boletín FVSA 9. Buenos Aires: Fundación Vida Silvestre. $38 \mathrm{p}$.

Chebez, J.C. 2007. Área Natural Protegida Provincial Meseta de Somuncurá; p. 348-349 In A.S. Di Giacomo, M.V. De Francesco and E.G. Coconier (ed.). Áreas importantes para la conservación de las aves en Argentina. Sitios prioritarios para la conservación de la biodiversidad. Buenos Aires: Aves Argentinas / Asociación Ornitológica del Plata.

Cortés, H.R., R.F. Masera, A. Dallorso and G. Serra Peirano. 1998. La gente y la economía del Somuncurá: Una aproximación a su estudio desde el análisis censal; p. 207-294 In R.F. Masera (ed.) La Meseta Patagónica del Somuncurá. Un horizonte en movimiento. $2^{\circ}$ edición revisada y ampliada. Viedma: Secretaría de Estado de Acción Social de Río Negro.

Cozzani, N., R. Sánchez and S. Zabala. 2004. Nidificación de la loica pampeana (Sturnella defilippii) en la provincia de Buenos Aires, Argentina. Hornero 19(1): 47-52.

Daciuk, J. 1979. Contribuciones sobre protección, conservación, investigación y manejo de la vida silvestre y áreas naturales. VI. Reserva Natural Integral de Somuncurá proyectada en Río Negro (Rep. Arg.). Physis C 38(94): 99-106.

de la Peña, M.R. 1988. Guía de Aves Argentinas. $1^{\circ}$ edición. Tomo V. Buenos Aires: L.O.L.A. 112 p.

de la Peña, M.R. 1989. Guía de Aves Argentinas. $1^{\circ}$ edición. Tomo VI. Buenos Aires: L.O.L.A. 125 p.

de la Peña, M.R. 1992a. Guía de Aves Argentinas. $2^{\circ}$ edición. Tomo I. Buenos Aires: L.O.L.A. $126 \mathrm{p}$.

de la Peña, M.R. 1992b. Guía de Aves Argentinas. $2^{\circ}$ edición. Tomo II. Buenos Aires: L.O.L.A. 166 p.

de la Peña, M.R. 1992c. Guía de Aves Argentinas. $2^{\circ}$ edición. Tomo III. Buenos Aires: L.O.L.A. 130 p.

de la Peña, M.R. and M. Rumboll. 1998. Birds of Southern South America and Antarctica. London: Harper Collins. 304 p.

del Río, J.L., M.J. Bó, A.M. López de Armentía, J.R. Álvarez, J. Martínez Arca, C. Wagner and M. Camino. 2005. Geomorfología descriptiva y ambiental de la costa oriental del golfo San Matías y la desembocadura del río Negro; p. 201-219 In R.F. Masera, J. Lew and G. Serra Peirano (ed.). Las mesetas patagónicas que caen al mar: la costa rionegrina. Viedma: Ministerio de Familia, Gobierno de Río Negro.

del Valle Moldes, B. 1998. Plumas, pieles, tejido y Ganado. Contribución al conocimiento de la transición del sector social con economía doméstica en Somuncurá; p. 75-206 In R.F. Masera (ed.). La Meseta Patagónica del Somuncurá. Un horizonte en movimiento. $2^{\circ}$ edición revisada y ampliada. Viedma: Secretaría de Estado de Acción Social de Río Negro.

Di Giacomo, A.S., M.V. De Francesco and E.G. Coconier. 2007. Áreas importantes para la conservación de las aves en Argentina. Sitios prioritarios para la conservación de la biodiversidad. Temas de
Naturaleza y Conservación 5. CD-ROM. Edición Revisada y Corregida. Buenos Aires: Aves Argentinas/Asociación Ornitológica del Plata. 515 p.

Failla M., M.L. Pagnossin, D. Paz Barreto, A. Pagnossin, M. Marchesan, P. Quillfeldt, C. Sommer and J.F. Masello. 2007. Villa Marítima El Cóndor. Donde la diversidad de aves contribuye con el turismo del nordeste patagónico. Naturaleza y Conservación 20: 24-30.

Fernández, G., G. Posse, V. Ferretti and F. Gabelli. 2003. Bird-habitat relationship for the Pampas meadowlark populations in the southern Pampas grasslands. Biological Conservation 115(1): 139-148.

Gabelli, F.M., G.J. Fernández, V. Ferretti, G. Posse, E. Coconier, H.J. Gavieiro, P.E. Llambías, P.I. Peláez, M.L. Vallés and P.L Tubaro. 2004. Range contraction in the Pampas Meadowlark Sturnella defilippii in the Southern Pampas grasslands of Argentina. Oryx 38(1): 164-170.

Gazari, R.R. 1967. Notas sobre algunas aves no señaladas o poco conocidas al sur del río Colorado. Hornero 10(4): 451-454.

González, P.M. 2005. Las aves migratorias. Las preguntas de la ida y vuelta de los chorlos y playeros entre los Hemisferios Sur y Norte. Su estadía temporaria en el Área Natural Protegida 'Bahía de San Antonio' y su reconocimiento como 'Sitio Internacional'. Estudio de su potencial ecoturístico. La declinación; p. 321-347 In In R.F. Masera, J. Lew and G. Serra Peirano (ed.). Las mesetas patagónicas que caen al mar: la costa rionegrina. Viedma: Ministerio de Familia, Gobierno de Río Negro.

González, P.M. 2007. San Antonio Oeste; p. 341-343 In A.S. Di Giacomo, M.V. De Francesco and E.G. Coconier (ed.). Áreas importantes para la conservación de las aves en Argentina. Sitios prioritarios para la conservación de la biodiversidad. Buenos Aires: Aves Argentinas / Asociación Ornitológica del Plata.

González, P., M. Carbajal, R.I.G. Morrison and A.L.J. Baker. 2004. Tendencias poblacionales del playero rojizo (Calidris canutus rufa) en el sur de Sudamérica. Ornitología Neotropical 15 (Suppl.): 357-365.

González, P.M., A.J. Baker and M.E. Echave. 2006. Annual survival of red knots (Calidris canutus rufa) using the San Antonio Oeste stopover site is reduced by domino effects involving late arrival and food depletion in Delaware Bay. Hornero 21(2): 109-117.

Guarido, J.C. 1998. Unidades geográficas Meseta de Somuncurá; p. 57 74 In R.F. Masera (ed.). La Meseta Patagónica del Somuncurá. Un horizonte en movimiento. $2^{\circ}$ edición revisada y ampliada. Viedma: Secretaría de Estado de Acción Social de Río Negro.

Guarido, J.C. 2001. Geografía Física - Departamento El Cuy - Provincia de Río Negro; p. 31-62 In R.F. Masera (ed.). La Meseta Patagónica de El Cuy. Una vasta soledad. Viedma: Secretaría de Estado de Acción Social de Río Negro.

Guarido, J.C. and M. Mazzitelli Mastricchio. 2003. Geografía. El Bajo del Gualicho; p. 23-57 In R.F. Masera and J.C. Guarido (ed.). Bajo del Gualicho: Una planicie patagónica bajo el nivel del mar. Realidad y leyenda. Viedma: Secretaría de Estado de Acción Social de Río Negro.

Jácome, N.L., V. Astore and M. Bertini. 2005. El retorno del Cóndor al Mar; p. 373-396 In R.F. Masera, J. Lew and G. Serra Peirano (ed.). Las mesetas patagónicas que caen al mar: la costa rionegrina. Viedma: Ministerio de Familia, Gobierno de Río Negro.

Kröpfl, A.L., G.A. Cecchi, N.M. Villasuso, E. Rossio and J.P. Pelotto. 2005. Manual de especies silvestres del Monte rionegrino. Viedma: Estación Experimental Agropecuaria Valle Inferior, INTA and Centro Universitario Regional Zona Atlántica, Universidad Nacional del Comahue. $184 \mathrm{p}$

Lambertucci, S.A., F. Barbar, C. Cabrera and M. Bertini. 2009. Comentarios sobre las Aves de la Sierra de Pailemán, Río Negro, Argentina Nuestras Aves 54: 81-87.

Lini, R.M., O. Sanguinetti, G. Zeppi, M. Alcalde and R.F. Masera. 2005. El estuario del río Negro. ¿Hacia un área natural protegida?; p. 441452 In R.F. Masera, J. Lew and G. Serra Peirano (ed.). Las mesetas patagónicas que caen al mar: la costa rionegrina. Viedma: Ministerio de Familia, Gobierno de Río Negro.

Masello, J.F. 2009. Natural wonder. IBA designation brings parrot colony closer to protection. PsittaScene 21(1): 10-11.

Masello, J.F. and P. Quillfeldt. 2003. The breeding colony of Burrowing Parrots in Patagonia. PsittaScene 15(4): 12-13.

Masello, J.F. and P. Quillfeldt. 2004a. Consequences of La Niña phase of ENSO for the survival and growth of nestling Burrowing Parrots on the Atlantic coast of South America. Emu 104(4): 337-346.

Masello, J.F. and P. Quillfeldt. 2004b. Burrowing Parrots news from El Cóndor, Patagonia, Argentina. PsittaScene 16(2): 7-9.

Masello, J.F. and P. Quillfeldt. 2005. La colonia de loros barranqueros en la costa rionegrina de El Cóndor. Un patrimonio mundial; p. 349-371 In R.F. Masera, J. Lew and G. Serra Peirano (ed.). Las mesetas patagónicas que caen al mar: la costa rionegrina. Viedma: Ministerio de Familia, Gobierno de Río Negro.

Masello, J.F. and P. Quillfeldt. 2007. Villa Marítima El Cóndor; p. 338-339 In A.S. Di Giacomo, M.V. De Francesco and E.G. Coconier (ed.). Áreas importantes para la conservación de las aves en Argentina. Sitios 
prioritarios para la conservación de la biodiversidad. Buenos Aires, Aves Argentinas / Asociación Ornitológica del Plata.

Masello, J.F., M.L. Pagnossin, C. Sommer and P. Quillfeldt. 2006. Population size, provisioning frequency, flock size and foraging range at the largest known colony of Psittaciformes: the Burrowing Parrots of the north-eastern Patagonian coastal cliffs. Emu 106(1): 69-79.

Masello, J.F., M. Failla, P. Giovine and P. Quillfeldt. 2007. Reserve status: parrot colony aims for legal protection. PsittaScene 19(4): 13-15.

Masello, J.F., T. Lubjuhn and P. Quillfeldt. 2008a. Is the structural and psittacofulvin-based colouration of wild Burrowing Parrots Cyanoliseus patagonus condition dependent? Journal of Avian Biology 39(6): 653-662.

Masello, J.F., M. Marchesan and P. Quillfeldt. 2008b. Zehn Jahre Forschung in der größten Papageienkolonie der Welt - Teil 1. Die Felsensittiche im Nordosten Patagoniens. Papageien 12: 426-429.

Masera, R.F. 1998. Breve caracterización de la Norpatagonia y el Somuncurá; p. 21-56 In R.F. Masera (ed.). La Meseta Patagónica del Somuncurá. Un horizonte en movimiento. $2^{\circ}$ edición revisada y ampliada. Viedma: Secretaría de Estado de Acción Social de Río Negro.

Masera, R.F. 2005. Fisonomía general del bordemar rionegrino; p. 1940 In R.F. Masera, J. Lew and G. Serra Peirano (ed.). Las mesetas patagónicas que caen al mar: la costa rionegrina. Viedma: Ministerio de Familia, Gobierno de Río Negro.

Mazar Barnett, J. and M. Pearman. 2001. Lista comentada de las aves argentinas. Barcelona: Lynx Edicions. $164 \mathrm{p}$.

Narosky, T. and D. Yzurieta. 1989. Birds of Argentina \& Uruguay. A field guide. Buenos Aires: Asociación Ornitológica del Plata. 337 p.

Narosky, T. and D. Yzurieta. 2003. Birds of Argentina \& Uruguay. A field guide. Edición de oro. Buenos Aires: Vazquez Mazzini Editores. 346 p.

Narosky, T. and D. Yzurieta. 2010. Birds of Argentina \& Uruguay. A field guide. $16^{a}$ edición. Buenos Aires: Vazquez Mazzini Editores. 432 p.

Navas, J.R. 1970. Nuevos registros de aves para la Patagonia. Neotrópica 16(1): 11-16.

Navas, J.R. and N.A. Bó. 1990. Apuntes sobre la meseta de Somuncurá, provincia de Río Negro. Neotrópica 36(95): 45-53.

Olivares, G. and A. Sisul. 2005. Hidrogeología de los campos costeros atlánticos rionegrinos; p. 235-247 In R.F. Masera, J. Lew and G. Serra Peirano (ed.). Las mesetas patagónicas que caen al mar: la costa rionegrina. Viedma: Ministerio de Familia, Gobierno de Río Negro.

Olrog, C.C. 1959. Las aves argentines. Una guía de campo. Tucumán: Universidad Nacional de Tucumán, Instituto "Miguel Lillo". 345 p.

Paz Barreto, D. 1997a. Aves de la provincia de Río Negro. I - Lista y bibliografía. Bariloche: Consejo de Ecología y Medio Ambiente. 12 p. Booklet accessible at https://sites.google.com/site/ areasnaturalesyguardaparques/home/documentos/aves. Captured on 01 November 2011.

Paz Barreto, D. 1997b. Aves de la provincia de Río Negro. II - Localidades confirmadas. Bariloche, Consejo de Ecología y Medio Ambiente. 25 p. Booklet accessible at https://sites.google.com/site/ areasnaturalesyguardaparques/home/documentos/aves. Captured on 01 November 2011.

Paz Barreto, D. 1997c. Un índice de valoración biogeográfica para sistemas de áreas protegidas, aplicado a la Provincia de Río Negro Rca. Argentina. Bariloche: Consejo de Ecología y Medio Ambiente, Provincia de Río Negro. 10 p.

Paz Barreto, D. 1998. Somuncurá: Reserva de la Biosfera; p. 397-407 In In R.F. Masera (ed.). La Meseta Patagónica del Somuncurá. Un horizonte en movimiento. $2^{\circ}$ edición revisada y ampliada. Viedma: Secretaría de Estado de Acción Social de Río Negro.

Paz Barreto, D. 2005. Listado de las áreas naturales protegidas de la costa rionegrina; p. 287-311 In R.F. Masera, J. Lew and G. Serra Peirano (ed.). Las mesetas patagónicas que caen al mar: la costa rionegrina. Viedma: Ministerio de Familia, Gobierno de Río Negro.
Pezzola, A., C. Winschel and R. Sánchez. 2004. Estudio multitemporal de la degradación del monte nativo en el partido de Patagones - Buenos Aires. Boletín Técnico Nro. 12. Buenos Aires: Ediciones Instituto Nacional de Tecnología Agropecuaria. 11 p.

Piacentini, H.A. and D. Paz Barreto. 2001. La Meseta Patagónica de El Cuy. Patagonia Extra Andina. Una introducción a la potencialidad de los recursos naturales; p. 385-398 In R.F. Masera (ed.) La Meseta Patagónica de El Cuy. Una vasta soledad. Viedma: Secretaría de Estado de Acción Social de Río Negro.

Piacentini, H.A. and A. Dallorso. 2005. Listado y registro fotográfico de algunas especies faunísticas de la costa rionegrina; p. 313-319 In R.F. Masera, J. Lew and G. Serra Peirano (ed.). Las mesetas patagónicas que caen al mar: la costa rionegrina. Viedma: Ministerio de Familia, Gobierno de Río Negro.

Rabuffetti, F. 2007. Reserva de Uso Múltiple de San Blas y Refugio de Vida silvestre complementario; p. 56-57 In A.S. Di Giacomo, M.V. De Francesco and E.G. Coconier (ed.). Áreas importantes para la conservación de las aves en Argentina. Sitios prioritarios para la conservación de la biodiversidad. Buenos Aires: Aves Argentinas / Asociación Ornitológica del Plata.

Real, R. and J.M. Vargas. 1996. The Probabilistic Basis of Jaccard's Index of Similarity. Systematic Biology 45(3): 380-385.

Roig, F.A., S. Roig-Juñent and V. Corbalán. 2009. Biogeography of the Monte Desert. Journal of Arid Environments 73(2): 164-172.

Roig-Juñent S., G. Flores, S. Claver, G. Debandi and A. Marvaldi. 2001. Monte Desert (Argentina): insect biodiversity and natural areas. Journal of Arid Environments 47(1): 77-94.

Torrejón, C. and S. Sawicki. 2005. Un estudio turístico. Síntesis de atractivos en la costa rionegrina; p. 459-475 In R.F. Masera, J. Lew and G. Serra Peirano (ed.). Las mesetas patagónicas que caen al mar: la costa rionegrina. Viedma: Ministerio de Familia, Gobierno de Río Negro.

Tubaro, P.L. and F.M. Gabelli. 1999. The decline of the Pampas meadowlark: difficulties of applying the IUCN criteria to neotropical grassland birds. Studies in Avian Biology 19: 250-257.

Vinci, C. 1998. El por qué del Área Natural Protegida "Reserva Natural Integral Meseta de Somuncurá”; p. 383-395 In R.F. Masera (ed.). La Meseta Patagónica del Somuncurá. Un horizonte en movimiento. $2^{\circ}$ edición revisada y ampliada. Viedma: Secretaría de Estado de Acción Social de Río Negro.

Vuilleumier, F. 1994. Nesting behavior, distribution, and speciation of Patagonian and Andean ground tyrants (Myiotheretes, Xolmis, Neoxolmis, Agriornis, and Muscisaxicola). Ornitología Neotropical 5(1): 1-55.

Wildlife Conservation Society (WCS) and Center for International Earth Science Information Network (CIESIN) Last of the Wild Data Version 2,2005 (LWP-2): Global Human Footprint data set (HF). Electronic Database accessible at http://www.wcs.org/humanfootprint/. Captured on 01 November 2011.

Zabala, C. and H. Freije. 2005. Geología de los acantilados rionegrinos; p. 185-199 In R.F. Masera, J. Lew and G. Serra Peirano (ed.). Las mesetas patagónicas que caen al mar: la costa rionegrina. Viedma: Ministerio de Familia, Gobierno de Río Negro.

RECEIVED: June 2011

LAST REVISED: August 2011

ACCEPTED: November 2011

Published online: December 2011

EDITORIAL RESPONSIBILITY: Dárius P. Tubelis 